http://dx.doi.org/10.11646/zootaxa.3811.4.2

http://zoobank.org/urn:Isid:zoobank.org:pub:99629EFB-F2F6-4DE8-AABA-D71069106912

\title{
New species and new records of Pterosthetops: eumadicolous water beetles of the South African Cape (Coleoptera, Hydraenidae)
}

\author{
DAVID T. BILTON \\ Marine Biology and Ecology Research Centre, Plymouth University, Drake Circus, Plymouth PL4 8AA, UK. \\ E-mail:d.bilton@plymouth.ac.uk
}

\begin{abstract}
Pterosthetops is one of a number of hydraenid genera endemic to the Cape of South Africa, whose minute moss beetle fauna is amongst the most diverse on earth. Here seven species are described as new: Pterosthetops baini sp. nov., Pterosthetops coriaceus sp. nov., Pterosthetops indwei sp. nov., Ptersothetops pulcherrimus sp. nov., Pterosthetops swartbergensis sp. nov., Pterosthetops tuberculatus sp. nov. and Pterosthetops uitkyki sp. nov., all from mountains in the Western Cape region. New collection records are also provided for all five previously described members of the genus, together with a revised key. Pterosthetops appear to be specialist inhabitants of seepages over rock faces (hygropetric/madicolous habitats), rarely being found outside such situations.
\end{abstract}

Key words: Coleoptera, Hydraenidae, Pterosthetops, new species, South Africa, ecology, new records

\section{Introduction}

The Western Cape of South Africa is famously home to one of the most diverse and highly endemic floras on earth (Manning \& Goldblatt 2012). Less well known is the fact that freshwater invertebrates in the region are also highly diverse and endemic, the mediterranean climate zone of the Western Cape being recognized as one of the world's 200 significant Freshwater Ecoregions (Theime et al. 2005; de Moor \& Day 2013). The combination of relative climatic stability since the Pliocene (Meadows \& Sugden 1991; Manning \& Goldblatt 2012) and the geological age of the Cape Fold Mountains, whose basic topography has remained relatively unchanged since the Caenozoic (65 MYA) are two factors contributing to this diversity, reducing extinction rates within lineages whilst at the same time promoting allopatric speciation.

The hydraenid beetle fauna of the Western Cape is one of the most phylogenetically, morphologically and ecologically diverse worldwide; a very high proportion of species and genera being endemic to the region, or to temperate South Africa, with maximum species richness in the west (see Perkins \& Balfour-Browne 1994; Bilton 2013 for details). Hygropetric/madicolous habitats (sensu Vaillant 1956), where a thin film of water runs over exposed, often vertical, rock faces appear to be particularly important for endemic Hydraenidae in the region (Perkins \& Balfour-Browne 1994; Perkins 2005; D.T. Bilton pers. obs.). Such habitats have been somewhat neglected by water beetle workers until relatively recently, but are now known to support specialist taxa in many parts of the world (e.g. Hájek \& Fikáček 2008; Clarkson \& Short 2012; Fikáček et al. 2012), some of which belong to novel, phylogentically isolated lineages (Ribera et al. 2002; Ribera \& Bilton 2007; Spangler \& Steiner 2005; Balke et al. 2008). The present paper deals with a hydraenid group which appears to belong to this specialist hygropetric fauna; Pterosthetops Perkins (in Perkins \& Balfour-Browne 1994).

Pterosthetops currently contains five described species (Perkins \& Balfour-Browne, 1994; Perkins, 2008), all of which are, like most other Prosthetopinae, endemic to South Africa. These beetles are rare in collections to date; only 99 specimens from 16 localities being examined amongst over 53,300 hydraenids studied by Perkins (2008; $2011 ; 2014)$. Recent targeted fieldwork by the author has resulted in the discovery of seven new species, as well as producing new collection records for all previously described taxa, significantly increasing our understanding of the diversity, ecology and biogeography of these beetles. 


\section{References}

Balke, M., Ribera, I., Beutel, R., Viloria, A., Garcia, M. \& Vogler, A.P. (2008) Systematic placement of the recently discovered beetle family Meruidae (Coleoptera: Dytiscoidea) based on molecular data. Zoologica Scripta, 37, 647-650. http://dx.doi.org/10.1111/j.1463-6409.2008.00345.x

Bilton, D.T. (2013) Description of the male of Sebasthetops omaliniformis Jäch, 1998 - a phylogenetically isolated water beetle from South Africa, with notes on its ecology (Coleoptera: Hydraenidae). Zootaxa, 3635 (1), 94-100. http://dx.doi.org/10.11646/zootaxa.3635.1.10

Biström, O. \& Nilsson, A.N. (2006) Taxonomic revision of the Ethiopian genus Canthyporus (Coleoptera Dytiscidae). Memorie della Società entomologica italiana, 85, 209-306. http://dx.doi.org/10.4081/memoriesei.2006.209

Clarkson, B. \& Short, A.E.Z. (2012) Revision of the Oocyclus Sharp of Brazil with description of ten new species (Coleoptera: Hydrophilidae: Laccobiini). Zootaxa, 3183, 1-35.

Daniels, S.R., McDonald, D.E. \& Picker, M.D. (2013) Evolutionary insight into the Peripatopsis balfouri sensu lato species complex (Onychophora: Peripatopsidae) reveals novel lineages and zoogeographic patterning. Zoologica Scripta, 42, $656-674$. http://dx.doi.org/10.1111/zsc. 12025

de Moor, F.C. (2011) A survey of Trichoptera from the Tributaries of the Doring and mainstream Olifants Rivers, Cedarberg, South Africa with implications for conservation. Zoosymposia, 5, 350-359.

de Moor, F.C. \& Day, J.A. (2013) Aquatic biodiversity in the Mediterranean region of South Africa. Hydrobiologia, 719, $237-268$. http://dx.doi.org/10.1007/s10750-013-1488-7

Endrödy-Younga, S. (1988) Evidence for the low-altitude origin of the Cape Mountain Biome derived from the systematic revision of the genus Colophon Gray (Coleoptera: Lucanidae). Annals of the South African Museum, 96, 359-424.

Fikáček, M., Leschen, R.A.B, Newton, A.F. \& Gunter, N. (2012) Horelophus walkeri rediscovered: adult morphology and notes on biology (Coleoptera: Hydrophilidae). Acta Entomologica Musei Nationalis Pragae, 52, 129-146.

Hájek, J. \& Fikáček, M. (2008) A review of the genus Satonius (Coleoptera: Myxophaga: Torridincolidae): taxonomic revision, larval morphology, notes on wing polymorphism, and phylogenetic implications. Acta Entomologica Musei Nationalis Pragae, 48, 655-676.

Manning, J.C. \& Goldblatt, P. (2012) The Greater Cape Floristic Region I: the Core Cape Flora. Strelitzia, $29,1-853$.

Perkins, P.D. (2005) A revision of the African hygropetric genus Coelometopon Janssens, and description of Oomtelecopon new genus (Coleoptera: Hydraenidae). Zootaxa, 949, 1-103.

Perkins, P.D. (2008) New species and new collection records of Prosthetopine water beetles from southern Africa (Coleoptera: Hydraenidae). Zootaxa, 1864, 1-124.

Perkins, P.D. (2011) New species and new collection records of aquatic beetles in the genus Ochthebius Leach from southern Africa (Coleoptera: Hydraenidae). Zootaxa, 3093, 1-34.

Perkins, P.D. (2014) A revision of the water beetle genus Hydraena Kugelann for southern Africa (Coleoptera: Hydraenidae). Zootaxa, 3758 (1), 1-92. http://dx.doi.org/10.11646/zootaxa.3758.1.1

Perkins, P.D. \& Balfour-Browne, J. (1994) A contribution to the taxonomy of aquatic and humicolous beetles of the family Hydraenidae in southern Africa. Fieldiana Zoology, 77, 1-159.

Ribera, I., Beutel, R.G., Balke, M. \& Vogler, A.P. (2002) Discovery of Aspidytidae, a new family of aquatic Coleoptera. Proceedings of the Royal Society of London Series B, 269, 2351-2356. http://dx.doi.org/10.1098/rspb.2002.2157

Ribera, I. \& Bilton, D.T. (2007) Aspidytidae. In: Staals, R. \& de Moor, I.J. (Eds.), Guides to the Freshwater Invertebrates of Southern Africa. Vol. 10. Coleoptera. Water Research Commission, Pretoria, pp. 85-88.

Spangler, P.J. \& Steiner, W.E. Jr. (2005) A new aquatic beetle family, Meruidae, from Venezuela (Coleoptera: Adephaga). Systematic Entomology, 30, 339-357. http://dx.doi.org/10.1111/j.1365-3113.2005.00288.x

Taylor, H.C. (1966) Cederberg Vegetation and Flora. Strelitzia, 3, 1-75.

Thieme, M.L., Abell, R., Stiassny, M.L.J., Skelton, P., Lehner, B., Teugels, G.G., Dinerstein, E., Toham, A.K., Burgess, N. \& Olson, D. (2005) Freshwater ecoregions of Africa and Madagascar, a Conservation Assessment, Island Press, Washington, USA, $431 \mathrm{pp}$.

Vaillant, F. (1956) Recherches sur la faune madicole de France, de Corse et d'Afrique du Nord. Memoires du Muséum National d'Histoire Naturelle Series A Zoologie, 11, 1-252. 